\title{
COMPARATIVE ANALYSIS OF STRUCTURAL $\Sigma$-CONVERGENCE OF EXPORTS
}

\author{
Vera Pirimova ${ }^{1}$
}

DOI: https://doi.org/10.31410/ITEMA.S.P.2020.93

\begin{abstract}
The paper analyses the structural $\sigma$-convergence of exports of six CEE countries to the Euro area. The countries are Estonia, Latvia, Lithuania, Slovakia, and Slovenia, which are members of the Euro area, as well as Bulgaria, which was included in the ERM II currency mechanism on 10.07.2020. The main goals are to measure and compare the structural $\sigma$ convergence of exports of the six CEE countries and to prove whether the introduction of the common currency (the euro) has an impact on the convergence. The research consists of the theoretical and empirical parts. The theoretical part systematizes basic concepts of economic, trade, club, and structural convergence. One index method used by his authors to study economic convergence has been adapted to the structural $\sigma$-convergence of exports. This is the dissimilarity index of Von Hagen and Traistaru. In the empirical part, the values of the index, by commodity groups, according to SITC, Rev. 4, for the six countries during the period 20022018 are determined. The index is calculated also as aggregated, referring to the total exports of the selected countries and for the whole period. The results are presented in graphical form. Based on them, the structural and dynamic characteristics of the convergence and divergence of exports of the six countries compared to the exports of the Euro area are derived. Conclusions are made about achieved the different degree of similarity, that is uncertain and unstable and so the convergence can be only partially attributed to the adoption of the euro. Methods of analysis and synthesis, induction and deduction, methods of the empirical index, and comparative analysis are applied.
\end{abstract}

Keywords: Convergence, Divergence, Export structure, Export dissimilarity Index.

\section{INTRODUCTION}

$\mathrm{C}$ onvergence problems have become an increasing scientific and practical significance in recent years. Different groups of countries from the European Union or other regions of the world are studied, evidence of the presence or absence of similarities in the development of the main macroeconomic processes is presented, criteria and methods to achieve nominal and real, as well as structural convergence, are applied. Some analyses reveal opportunities for synchronizing the dynamics of economies (GDP growth), using methods that allow studying other processes and indicators, including similarities or differences in the field of foreign trade. They become more in-depth by the detection of signs of convergence or divergence in the structural characteristics of GDP and foreign trade. Theoretical and empirical analyses summarize many factors of convergence, discuss the role of the adoption and use of the common European currency (euro) for the Euro area and European Union countries.

The problems of structural convergence in the field of exports acquire new significance for Bulgaria after the inclusion of the country and the Bulgarian lev in the currency mechanism

University of National and World Economy (UNWE), Sofia, Bulgaria, bul. 8th December, Students town, Sofia 1700, Bulgaria 
ERM II on July 10, 2020. In the context of Bulgaria's future membership in the Euro area, it is interesting to compare it with other EU countries, such as those in the CEE region, which have already adopted the euro and have similar starting economic conditions.

In this context, the main objective of the present study is to determine the structural $\sigma$ convergence of exports of six CEE countries to exports of the Euro area as a whole. The group of countries includes Bulgaria and the five countries from the region of Central and Eastern Europe, which already use the euro (Estonia, Latvia, Lithuania, Slovenia, and Slovakia).

To achieve the main goal, several more specific tasks are solved, including:

1. Theoretical and methodological analysis is performed, in which dependencies between the economic, trade, structural, and club convergence are revealed, through the prism of the possibilities for application of certain combined methods for their analysis;

2. An empirical index and comparative analysis shall determine the extent and trends of convergence change in the selected group of six CEE countries. An additional task is to prove whether the introduction of the euro has an impact on the convergence process.

The methods of analysis and synthesis, induction and deduction, as well as the methods of empirical, comparative, and mathematical-statistical (index) analysis are applied. To determine the structural $\sigma$-convergence of exports, the values of the dissimilarity index by the method of Von Hagen and Traistaru are calculated. This index is subject to some modification and adaptation insofar as it is applied as a rule for the analysis of structural economic convergence. The values of the index are calculated for each of the six CEE countries, for seven commodity groups, subdivided according to SITC, rev. 4, by individual years in the period 2002-2018. Also, the values of the aggregated index (for all exports), for each year of the period, for the six CEE countries have been measured. The results are expressed in absolute value (under module) and are illustrated with graphs. Eurostat data on an annual basis are used in the analysis.

\section{THEORETICAL AND METHODOLOGICAL BASES OF THE ANALYSIS}

The analyses of achieving greater similarity between EU countries reveal in several areas the relationship between beta and sigma convergence, as well as between economic, trade, structural, and club convergence. On this basis, it is possible to apply similar methods to determine the degree and trends in the dynamics of structural economic and trade convergence/divergence.

As a result of the development of integration, the ties between the economies are deepened and trade between the EU countries is expanded. On this basis, and given the share of exports and imports in the GDP indicator, it becomes possible to examine economic and trade convergence in parallel. This is clearly expressed in the application of the basic methods and models of the neoclassical and endogenous theory of economic growth. A study by Devasmita Jena and Alokesh Barua (2020) summarizes that based on the model of Solow (1956) and Swan (1956) many empirical analyses of convergence have been performed, reflected for example in Barro (1991), Barro and Sala-i-Martin (1991, 1992, 1997, 2003), Sala-i-Martin (1996), Quah (1996), Bernard and Durlauf (1996), Rodrik (2003, 2011) and others. It is underlined, that as early as the 1990s in the analyses of Barro and Sala-i-Martin (1991, 1992), the basic principles of beta and sigma convergence were developed. Besides, Quah (1996) and Sala-i-Martin (1996) express the view that the presence of beta convergence is a prerequisite for achieving sigma convergence. Therefore, in order to reduce the differences between countries in the created per 
capita income over time (sigma-convergence), income must grow faster in relatively poorer countries than in richer countries (beta-convergence).

The theoretical is supplemented by empirical comparative models. They focus on certain groups of countries and allow to reveal the peculiarities of the so-called "club" convergence. It was introduced as a term by Baumol (1986), which proves that groups of countries with similar initial structural characteristics of economies can show a tendency to converge, to achieve a sustainable balance through a relatively balanced growth path. Many studies have concluded that club convergence analysis provides a more realistic view of regional income growth and hence of regional convergence than traditional concepts of beta-convergence and sigmaconvergence (e.g. Durlauf et al, 2005; Quah, 1996). The results of Barro (1991), Mankiw et al. (1992), Barro and Sala-i-Martin (1991, 1992), confirm the view that the conditional convergence corresponds to a large extent to the club's convergence. The relationship between these two types of convergence is also argued by Alexiadis (2013). He emphasizes that theoretical grounds for the concept of club convergence can be found in neoclassical and some endogenous growth models. According to him, the economies are not converging, there is a certain polarization of regions, poor "peripheral" regions, and rich "central" regions are divided, with growing differences between them. Alexiadis emphasizes the similar characteristics of "clubs" of different countries in Europe, not only in terms of geography but also in terms of the creation and implementation of technologies and the external influences of the agglomeration. In other analyses, the club is linked and studied by the methods of beta convergence (see in more detail the summaries of Varbanov (2020) and its other factors are supplemented.

Based on the dependencies between conditional and club convergence, Borsi and Metiu (2015) differentiate four convergence clubs within the EU-27. According to them, the creation of these clubs is based on geographical regions, not on membership in the European Union. On the other hand, Lyncker and Thoennessen (2015) adduce arguments for club convergence in the EU-15, while in terms of divergence, they found differences in income growth in Northern, Central, and Southern Europe. Scharpf (2016) emphasizes the "monetary over-integration of structurally heterogeneous "northern" and "southern" political economies" and proposes the possibility of moving towards a "system of differentiated monetary integration that could adopt structurally diverse and highly interdependent European political economies".

In a similar context, the present study focuses on the structural sigma convergence in the exports of a certain group (club) of six EU countries, which are characterized by initial similarity in economic conditions. Conclusions from beta convergence analyses have been taken into account that relatively lagging countries can achieve higher rates of economic growth and faster intensification of their trade flows with more advanced countries. However, these conclusions are not definite and unambiguous. On the one hand, there are arguments in support of the concepts of beta and sigma convergence, for example in the research of Armstrong (1995); Ben-David (1993, 2001); Dewhurst and Mutis-Gaitan (1995); Leonardi (1995); Kutan and Yigit (2009); Boldrin and Canova (2001); Barua et al. (2006); Villaverde and Maza (2008); Dobrinsky (2013); Próchniak and Witkowski (2013); Campos et al. (2014); Goedemé and Collado (2016). On the other hand, there is a simultaneous evidence of both convergence and divergence in certain indicators or in certain periods (Marques and Soukiazis (1998); Dunford (1996); Simionescucu (2014)). There are also generalizations in which only signs of divergence predominate (Arestis and Paliginis (1995); Hallett (1981); Slaughter (1997, 2001)). From such a point of view, it is of interest to determine whether trends of expansion 
(or restriction) of structural convergence (divergence) of exports of the six CEE countries to the Euro area prevail.

In the present analysis it is recognized that the notions of convergence in the economy and foreign trade are improved with the development of the understanding and empirical analyses of the structural convergence. It presupposes achieving similarity in the commodity structure of exports and imports, which is also linked to the sectoral structure of the economies. Depending on the degree of disaggregation of the indicators used, the degree of similarity or difference in the specialization of production and exports of groups of EU and world countries is determined. In recent years, a huge variety of theoretical models and empirical analyses have been developed, focused on the problems of structural convergence in foreign trade (see in more details Pirimova, 2019a, 2019b). Among them are, for example, studies by Derado (2008), Benedictis and Tajoli (2007), Nikolić (2011), Erlat and Ekmen (2009), Kaitila (2013), Joseph and Osbat (2016), etc.

Taken into account the relationship between economic and trade convergence in the empirical part of the present study, the $\sigma$-convergence method is applied. It has been previously adapted by us to the analysis of structural trade convergence, insofar as in its original form it has been constructed and applied for the analysis of structural economic convergence/divergence.

Here, a dissimilarity index (DISSIM) compiled by Von Hagen and Traistaru (2005) is calculated. In its original form, this index represents the structural $\sigma$-convergence of a country's economy, for which purpose the share of one economic sector in the GVA of the respective country is compared with the share of the same sector in the reference group of countries (Euro area). After adapting to the structural convergence in exports, the basic equation retains its general form:

$$
\operatorname{DISSIM}_{\mathrm{nx}}=-\sum\left|\mathrm{E}_{\mathrm{nx}}-\mathrm{E}_{\mathrm{EZx}}\right|
$$

however, the following indicators have been introduced and used:

$\mathrm{E}_{\mathrm{nx}}$ is the relative share of a given product group $x$ in the exports of the respective CEE country $n$ (Bulgaria, Estonia, Latvia, Lithuania, Slovenia, Slovakia);

$\mathrm{E}_{\mathrm{EZx}}$ is the relative share of the same commodity group $x$ in the exports of the Eurozone (EZ the reference group of countries).

The dissimilarity index (DISSIM) is calculated based on Eurostat annual data and preliminarily calculated by us relative indicators for the exports of Bulgaria and the other five CEE countries toward the Euro area, for each of the seven commodity groups, according to SITC, rev. 4, for the period 2002-2018. The commodity groups are: 1.) food, drinks and tobacco; 2.) raw materials; 3.) mineral fuels, lubricants and related materials; 4.) chemicals and related products, n.e.s.; 5.) other manufactured goods; 6.) machinery and transport equipment; 7.) commodities and transactions not classified elsewhere in the SITC. In addition, aggregated values of the index for the export for each year of the period have been calculated. This allows for the whole past period to express the prevailing generalized trends of change and transition to greater resemblance (convergence) or distinction (divergence) in the structural characteristics of exports of each of the six countries relative to Euro area exports. The results are presented in absolute values, graphs are built on their basis.

When interpreting the obtained results, it is taken into account that if the values of the submodule indices are small and tend to zero, they are a sign of weaker divergence and respectively 
stronger structural convergence, i.e. for greater convergence (or complete coincidence at DISSIM $=0$ ) of the exports of a certain commodity group from a given CEE country to the exports of the same commodity group from the Euro area as a whole. At higher values of the indices there are more significant differences, stronger divergence (rather than convergence) in the commodity structure of exports of a particular country to the reference group of Euro area countries. As an illustration, the graph lines appear lower and closer (in convergence) or higher and further away (in divergence) from the abscissa, giving a graphical expression of the Euro area export reference values.

\section{STRUCTURAL $\Sigma$-CONVERGENCE OF EXPORTS OF SIX CEE COUNTRIES TO THE EURO AREA}

The results obtained for the DISSIM index are relatively low, but different by countries, years and commodity groups in exports. All values are in the range between 0 and 1, i.e. $1>$ DISSIM $>0$, sometimes lower and tending to zero, but in no case equal to 0 . Based on them, mixed, ambiguous conclusions can be made - in some cases, there are signs of greater convergence, while in other cases there is still greater divergence in exports.

According to the values of the DISSIM dissimilarity index, several commodity groups stand out, in which each of the six countries shows the greatest similarities with the exports of the similar commodity group from the Euro area (see Table 1). For these commodity groups, the values of the index are relatively low, sometimes closer to zero. Therefore, the six CEE countries have achieved comparative similarity (convergence) with Euro area exports. The graphs (see Fig. 1 to Fig. 6) clearly show that their dynamic lines are the lowest, i.e. they are characterized by a maximum approximation to the abscissa and therefore to the reference values for Euro area exports.

Table 1. Commodity groups in the exports of six CEE countries with the greatest similarity (convergence) with the exports of the Euro area according to the DISSIM index*

\begin{tabular}{|c|c|}
\hline Country & $\begin{array}{l}\text { The greatest similarity with the exports of the Euro area according to the } \\
\text { DISSIM index }\end{array}$ \\
\hline Bulgaria & $\begin{array}{l}\text { 1. commodities and transactions not classified elsewhere in the SITC } \\
\text { 2. food, drinks and tobacco } \\
\text { 3. raw materials }\end{array}$ \\
\hline Estonia & $\begin{array}{l}\text { 1. food, drinks and tobacco } \\
\text { 2. commodities and transactions not classified elsewhere in the SITC } \\
\text { 3. other manufactured goods }\end{array}$ \\
\hline Latvia & $\begin{array}{l}\text { 1. commodities and transactions not classified elsewhere in the SITC } \\
\text { 2. mineral fuels, lubricants and related materials } \\
\text { 3. other manufactured goods }\end{array}$ \\
\hline Lithuania & $\begin{array}{l}\text { 1. raw materials } \\
\text { 2. other manufactured goods } \\
\text { 3. commodities and transactions not classified elsewhere in the SITC }\end{array}$ \\
\hline Slovakia & $\begin{array}{l}\text { 1. raw materials } \\
\text { 2. commodities and transactions not classified elsewhere in the SITC } \\
\text { 3. mineral fuels, lubricants and related materials }\end{array}$ \\
\hline Slovenia & $\begin{array}{l}\text { 1. raw materials } \\
\text { 2. commodities and transactions not classified elsewhere in the SITC } \\
\text { 3. mineral fuels, lubricants and related materials }\end{array}$ \\
\hline
\end{tabular}

Source: Author's systematization based on own calculations of the DISSIM index values according to Eurostat annual data. 
Figure 1. DISSIM index, by commodity groups for Bulgaria's exports to the Euro area

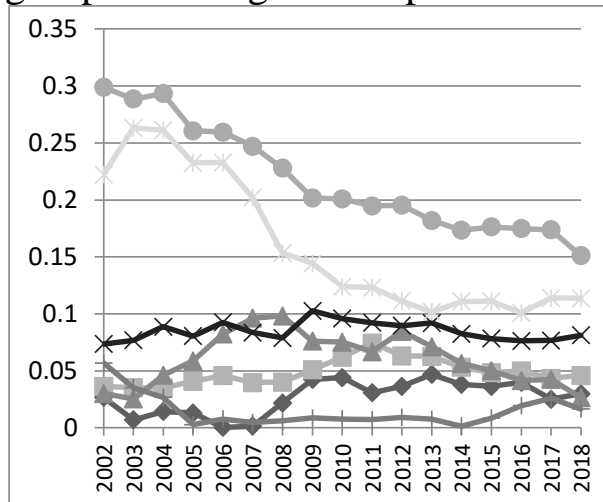

Source: Author's calculations based on Eurostat data.

Figure 3. DISSIM index, by commodity groups for Latvia's exports to the Euro area
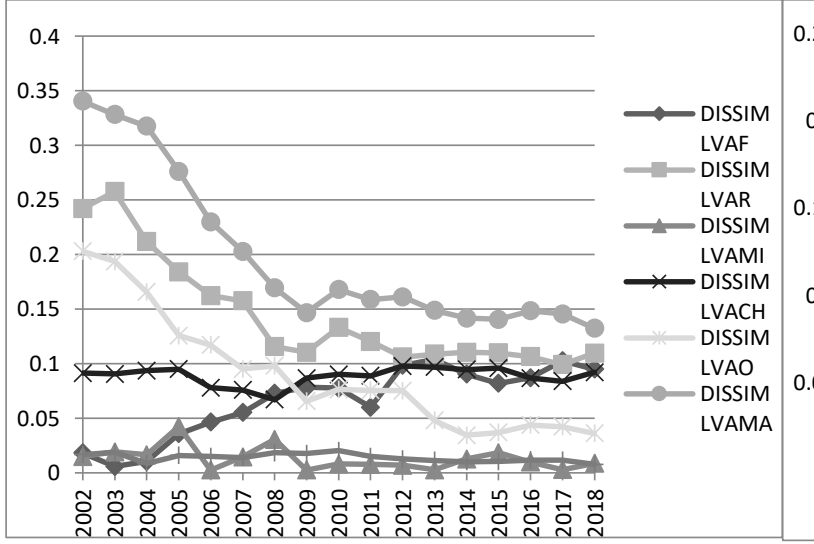

Source: Author's calculations based on Eurostat data.

Figure 5. DISSIM index, by commodity groups for Slovakia's exports to the Euro area

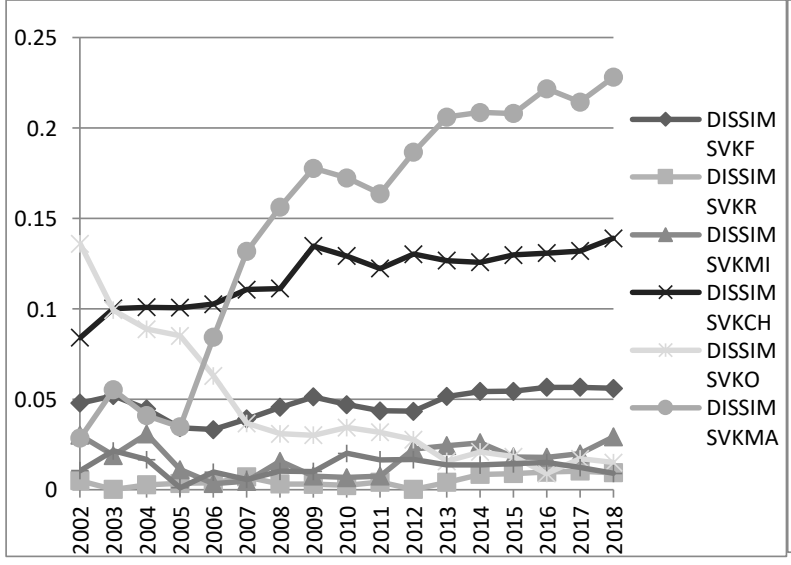

Source: Author's calculations based on Eurostat data.
Figure 2. DISSIM index, by commodity groups for Estonian exports to the Euro area

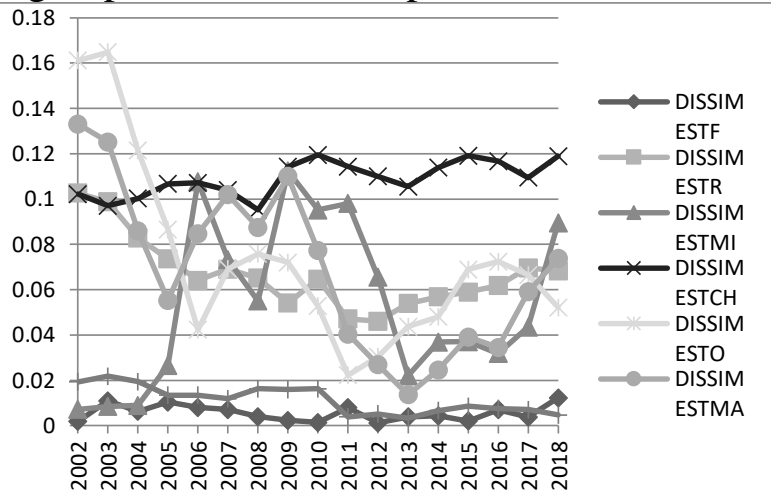

Source: Author's calculations based on Eurostat data.

Figure 4. DISSIM index, by commodity groups for Lithuanian exports to the Euro area

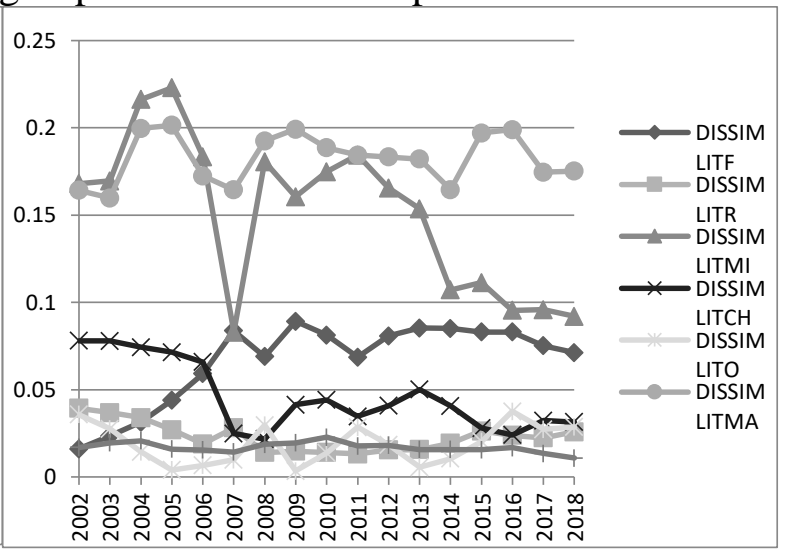

Source: Author's calculations based on Eurostat data.

Figure 6. DISSIM index, by commodity groups for Slovenia's exports to the Euro area

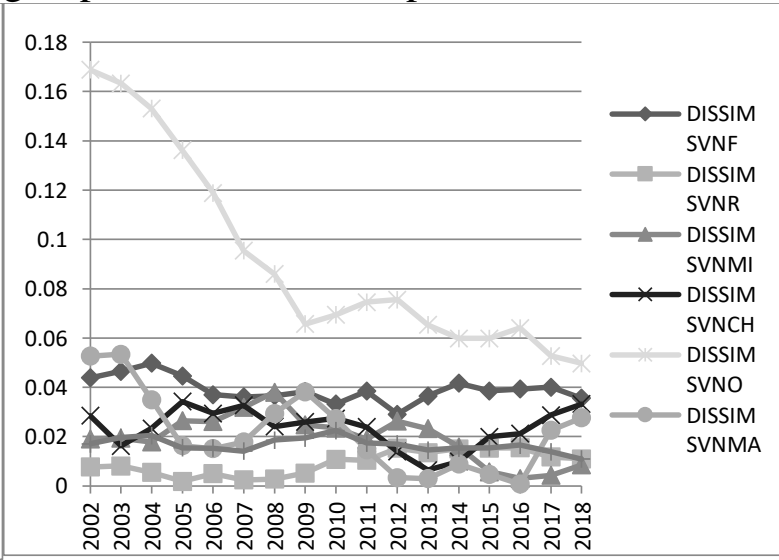

Source: Author's calculations based on Eurostat data. 
The ranking of the first three commodity groups with the lowest DISSIM indices, on which comparative structural convergence with the Euro area exports was achieved, does not show significant differences between countries. By one specific commodity group - "commodities and transactions not classified elsewhere in the SITC", all six CEE countries have a relatively strong similarity to Euro area exports. However, the index values vary from country to country, and this commodity group is not always in the first place or the same place. It has the lowest DISSIM indices and ranks first for Bulgaria and Latvia, second for Estonia, Slovakia and Slovenia, third for Lithuania. Another commodity group, which is more represented because four of the countries (Bulgaria, Lithuania, Slovakia and Slovenia) achieve a relatively large approximation to the exports of the Euro area, is the group of "raw materials". It is followed by "other manufactured goods" included in the forefront in three of the countries (Estonia, Latvia and Lithuania), as well as "mineral fuels, lubricants and related materials" - also in three countries (Latvia, Slovakia and Slovenia).

Regarding the dynamics of structural convergence by individual commodity groups, the change in the values of the DISSIM index must be monitored. They are declining almost continuously and consistently for most commodity groups, for four countries (Bulgaria, Latvia, Lithuania and Slovenia) and thus show a gradual reduction in their structural divergence with Euro area exports. A different and not always positive trend is realized by separate commodity groups for Estonia (where there are uneven, frequent and divergent fluctuations) and by some commodity groups for Slovakia (where there is an increase in divergence). Indicative of this is the form and orientation of the graphical lines of the DISSIM indices by the respective commodity groups and countries.

In order to draw certain conclusions about the role of the euro, the peculiarities of structural convergence should be compared, on the one hand, for the exports of Bulgaria, and on the other hand, for the exports of the other five CEE countries. The results and conclusions are not unconditional for all commodity groups and all other CEE countries. On this basis, it cannot be indisputably proven that the introduction of the common currency is one of the leading and sustainable factors for greater structural convergence of exports.

It has already been shown that according to the calculated values of the DISSIM index there is no great peculiarity for Bulgaria in comparison with the other five CEE countries (members of the Euro area) in terms of the leading convergent commodity groups. There is a certain difference in the fact that in some cases the values of the DISSIM index for Bulgaria are higher and with relatively larger amplitudes (by years and by commodity groups), compared to the other five countries. Thus, in the past period, the degree of achieved structural convergence of Bulgarian exports can be defined as lower. At the same time, however, Bulgaria (as well as Latvia and Lithuania) is characterized by a steady trend of growing structural similarity with Euro area exports during the period - the dynamic lines of all seven commodity groups are downward. It is specific for Bulgaria that the structural convergence is more pronounced for commodity groups with a lower degree of product processing - because only for Bulgaria in the groups with the lowest values of the index are included simultaneously "food, drinks and tobacco" and "raw materials". However, this may be due to the different sectoral structure of the economies of Bulgaria and the other five CEE countries, as well as the relative shares of the respective commodity groups in GDP and the total exports of the six countries. For these reasons, at the beginning of the period, the weakest convergence was in the exports from Bulgaria of the commodity groups "machinery and transport equipment" and "other manufactured goods". The lines of their DISSIM indices are then significantly above the DISSIM lines of the other commodity groups. But over the years there has been a steady trend 
of narrowing the gap, gradually descending and bringing the lines closer to those of other commodity groups and the Euro area. Nevertheless, these two commodity groups continue to dominate the difference in 2018 (when their lines remain the highest, above the lines of other commodity groups).

The insufficiently strong or emphasized role of the euro is also evident in the trends in the change of structural convergence, respectively divergence of exports as a whole. They can be derived based on calculated aggregated indices of dissimilarity (Aggregated DISSIM index) by country, for each year of the period.

Figure 7. Aggregate DISSIM Index of Bulgaria, Estonia, Latvia, Lithuania, Slovakia and Slovenia

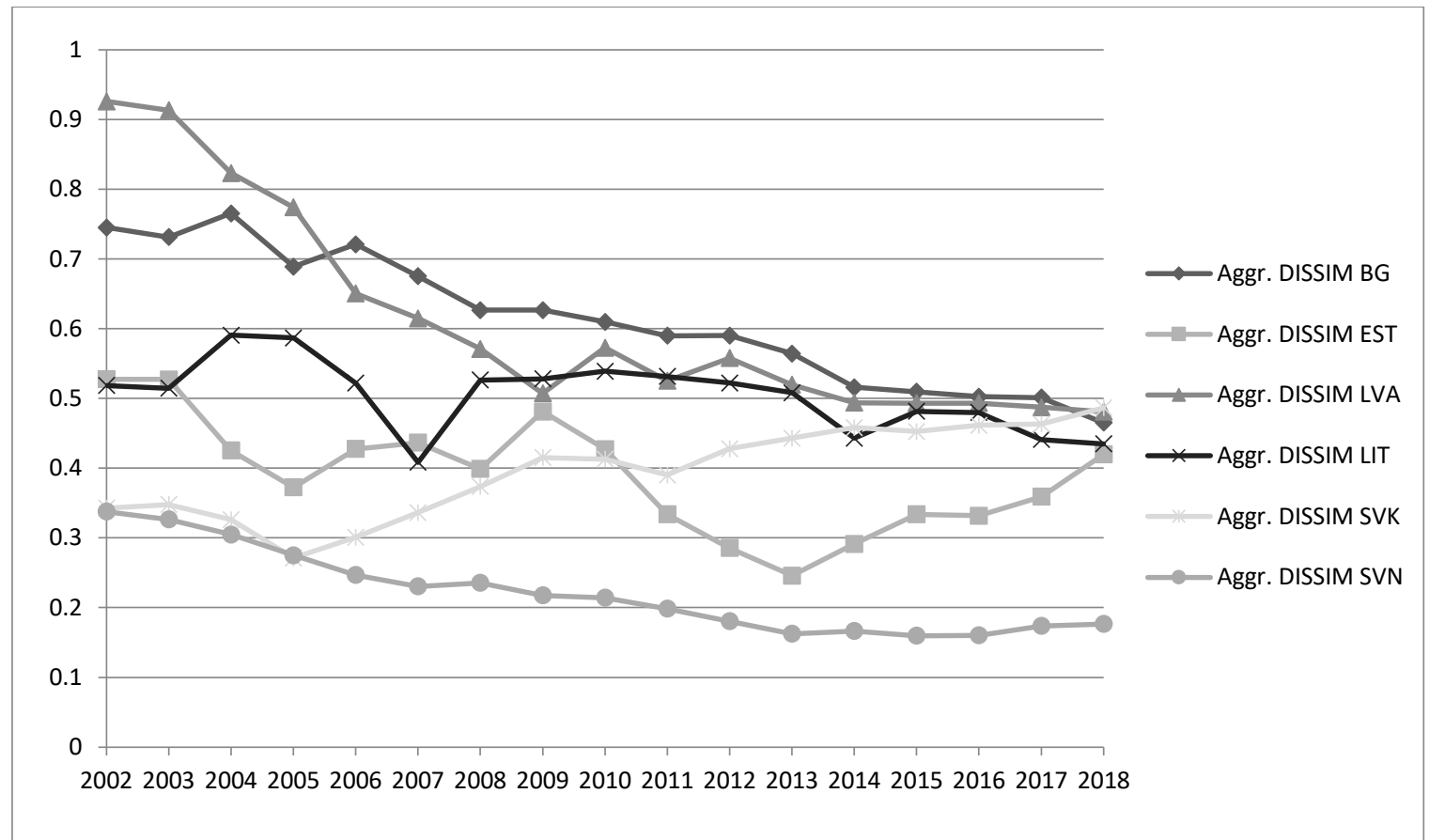

Source: Author's calculations of the values of the Aggregated DISSIM index according to Eurostat data.

The Aggregated DISSIM indices and the graphical lines based on them (see Fig. 7) show a peculiarity in the reduction or expansion of the similarity in exports with the Euro area achieved by each country. For the outstanding generalized trends in the structural convergence of exports in the period 2002-2018, the following conclusions can be made by country:

- For Bulgaria, there is a steady trend of increasing structural convergence in exports compared to exports of the Euro area within the study period. This trend is confirmed by the declining values of the Aggregated DISSIM index and their graph line, which is descending. At the beginning of the period, the differences are larger, towards the end of the period the values of the index decrease (from 0.74 to 0.46 ), exceeding the typical for three other CEE countries. Thus, the structural convergence of Bulgarian exports is growing, being comparable to that of Latvia and Slovakia, but remains weaker than that of the other three CEE countries, members of the Euro area. The line of Aggregated DISSIM for Bulgaria is the highest almost throughout the period, for 2018 it overlaps with the lines of Latvia and Slovakia.

- For 2018, Estonia is in second place in terms of the degree of convergence in exports among the six CEE countries. However, it is characterized by uneven changes and 
frequent fluctuations in the values of the Aggregated DISSIM index, without an unconditional trend of greater convergence. The graphical line of the index is wavy and even ascending in the last few years, i.e. contains signs of deviation from Euro area reference values. Although the differences with the exports of the Euro area countries decreased from 2008 to 2013, then and towards the end of the period, the divergence in exports increased.

- The revealed generalized tendencies for Latvia are similar to those for Bulgaria. From the highest value of the Aggregated DISSIM index for all six countries in 2002, after its successive decrease, greater structural convergence of exports was reached at the end of the period. For 2018, the values of the index are almost equal to those for Bulgaria and are the highest for the six CEE countries. Thus, Latvia and Bulgaria (and Slovakia) find themselves lagging behind in the convergence of exports to the Euro area, compared to the other three CEE countries. It is specific to Latvia that after 2008-2009 and especially after 2013 the convergence in exports remains at a relatively constant level, the graph line becomes approximately horizontal.

- Lithuania is characterized by fluctuations and separate increases in the divergence in exports in the first years of the period and until 2008. After that, the change of the Aggregated DISSIM index becomes smoother and more gradual, with a slight increase in convergence until 2018.

- Slovakia is the only one of the six CEE countries for which there is a steady negative trend of increasing divergence and declining convergence in exports compared to that of the Euro area. Until 2005 there was a definite decrease in Aggregated DISSIM, but then began and continued until the end of the period increase in the values of the index. As a result, in 2018 Slovakia turned out to be the country with the highest Aggregated DISSIM index (0.49) and a clear upward graph.

- Slovenia is the country that has achieved the greatest convergence in exports of the six CEE countries. For it, the values of Aggregated DISSIM are the lowest (falling from 0.33 in 2002 to 0.17 in 2018), the graphics line is the lowest and significantly below that of other countries. This is also the country that shows a well-defined and smooth trend of increasing convergence in exports during the period.

Based on the Aggregated DISSIM index, different, not always positive trends in the change of convergence in exports of the five CEE countries, members of the Euro area, were highlighted. The key role of the common currency in deepening convergence has not been established, as trends do not change significantly immediately after the year of the introduction of the euro in Slovenia (2007), Slovakia (2009), Estonia (2011), Latvia (2014), Lithuania (2015). Although it still uses its national currency, Bulgaria is achieving increasing structural convergence of exports to the Euro area. On this basis, there are insufficient grounds to expect that the forthcoming introduction of the euro in Bulgaria will significantly contribute to greater structural convergence of exports. It is likely that other internal or external factors will have a more significant impact on the convergence of Bulgaria's exports in the coming years.

\section{CONCLUSION}

In consequence of the performed theoretical and methodological analysis, the application of some similar methods for studying the structural economic and trade convergence was justified. As a result of the empirical index and comparative analysis, the structural and dynamic characteristics of the convergence in exports of Bulgaria (in which the introduction of the euro is forthcoming) and the other five CEE countries (that already use the euro) to Euro area exports were derived. 
Based on the obtained values of the DISSIM index for the period 2002-2018, it was concluded that Bulgaria and the Euro area have a growing degree of export similarity and a relatively achieved convergent commodity structure of exports. The convergence trend is more pronounced in relation to some of the studied product groups. There are some similarities between the six CEE countries in achieving greater convergence across some commodity groups.

The structural similarities in exports can be interpreted as a challenge for the six CEE countries because they express increasing competitive pressure, the need to increase the competitiveness of production, quality, technical characteristics of goods involved in their exports to the EU and the Euro area.

The results obtained are not unambiguous, indicating both convergence and still available divergence in exports. Slovenia, Bulgaria and Latvia have a steady trend of increasing convergence during the period. Limiting convergence and expanding divergence is typical of Slovakia. For the other two countries - Latvia and Lithuania, after the middle of the period there is a retention of the achieved degree of convergence. For Estonia, there is marked instability and frequent fluctuations, with a predominant increase in the divergence in exports compared to the Euro area. The five CEE countries have been admitted to the Euro area at different times, no link has been established between the year of accession and the duration of their membership in the Euro area, on the one hand, and the dynamic characteristics of the structural convergence of their exports, on the other.

Therefore, the introduction of the euro is neutral or does not have a significant impact on the structural sigma convergence of the studied group of countries to the Euro area. However, given its stimulating effects on the growth of regional trade within the EU, it can be expected that the trend of deepening Bulgaria's trade convergence towards the Euro area will continue after the real introduction of the euro.

Given the diverse dynamic features and structural specifics, there are not enough signs and indirect grounds to support the reveal of club convergence in the exports of the selected six CEE countries.

\section{REFERENCES}

Alexiadis St., (2013) Convergence Clubs and Spatial Externalities. Models and Applications of Regional Convergence in Europe, Springer-Verlag Berlin Heidelberg.

Arestis, P., \& Paliginis, E. (1995). Divergence and peripheral Fordism in the European Union, Review of Social Economy, pp. 261-283.

Armstrong, H. W. (1995). Convergence among regions of the European Union 1950-1990, Papers in Regional Science, 74, pp. 125-142

Barro, R. (1991), Economic growth in a cross section of countries. Quarterly Journal of Economics, 106, pp. 407-443.

Barro, R. J., \& Sala-i-Martin, X. (1991). Convergence across states and regions. Brookings papers on economic activity, pp. 107-182.

Barro, R. J., \& Sala-i-Martin, X. (1992). Convergence, Journal of Political Economy, 100, pp. 223-251.

Barro, R. J., \& Sala-i-Martin, X. (1997). Technological diffusion, convergence and growth, Journal of Economic Growth, 2, pp. 1-26.

Barro, R., \& Sala-i-Martin, X. (2003). Economic growth. Cambridge - London: The MIT Press. 
Barua, A., Sauernheimer, K., \& Mohr, T. (2006). Globalization, unification and income inequality in Europe: Some new empirical evidence.

Baumol, W. J. (1986). Productivity growth, convergence, and welfare: What the long-run data show, American Economic Review, LXXVI (1986), pp. 1072-1085.

Ben-David, D. (1993). Equalizing exchange: Trade liberalization and income convergence, Quarterly Journal of Economics, 108 (3)

Ben-David, D. (2001). Trade liberalization and income convergence: A comment, Journal of International Economics, Elsevier, 55(1), pp. 229-234.

Benedicts, L., Tajoli, L. (2007), Economic integration and similarity in trade structures, Empirica, 2007 - 34, pp. 117-137

Bernard, A., Durlauf, S. (1996). Interpreting tests of the convergence hypothesis, Journal of Econometrics, 71, pp.161-173.

Boldrin, M., \& Canova, F. (2001). Inequality and convergence in Europe's regions: Reconsidering European regional policies, Economic Policy (April 2001).

Borsi, M. T., \& Metiu, N. (2015). The evolution of economic convergence in the European Union, Empirical Economics, 2015(48), pp. 657-681

Campos, N. F., Coricelli, F., \& Moretti, L. (2014). Economic growth and political integration: Estimating the benefit from membership in the European Union using the synthetic counterfactuals method, IZA discussion paper 8162, 2014, https://ssrn.com/abstract=2432446

Derado, D., (2008), Effects of The Eastern EU-Enlargement On Croatia - A Trade Analysis, Management, 2008 - 13, pp. 37-58, https://hrcak.srce.hr/file/40230

Devasmita Jena, Alokesh Barua (2020), Trade, governance and income convergence in the European Union: Evidence on the "theory of relative backwardness", Research in Globalization, 2 , 2020 , https://reader.elsevier.com/reader/sd/pii/S2590051X20300022?token=43CFA43754021 CF4D59A55FD8EDEB25A11F804915AF25641FC0D84CC5A0D5F22F3AED363D18 CD74FB4B23B2F81A361C1

Dewhurst, J. H., \& Mutis-Gaitan, H. (1995). Varying speeds of regional GDP per capita convergence in the European Union, 1981-91. In: H. W. Armstrong, \& R. W. Vickerman (Eds.), Convergence and divergence among European regions, pp. 22-39, London: Pion.

Dobrinsky, R. (2013). What is happening to growth in Europe? Research report, no 385, the Vienna Institute for International Economic Studies (wiiw), February.

Dunford, M. (1996). Disparities in employment, productivity and output in the EU: The roles of labour market governance and welfare regimes, Regional Studies, 30, pp. 339-357.

Durlauf, S. N., Johnson, P., \& Temple, J. (2005). Growth econometrics. In: P. Aghion, \& S. N. Durlauf (Eds.), Handbook of economic growth. Amsterdam: North Holland.

Erlat G., S. Ekmen, (2009), Export Similarity And Competitiveness: The Case Of Turkey in The EU Market, Paper presented at EconAnadolu 2009: Anadolu International Conference in Economics, June 17-19, 2009, Eskişehir, Turkey, http://citeseerx.ist.psu.edu/viewdoc/download?doi=10.1.1.536.1654\&rep=rep1\&type=p df

Goedemé, T., \& Collado, D. (2016). The EU convergence machine at work. To the benefit of the EU's poorest citizens?, Journal of Common Market Studies, 2016, p. 54.

Hallett, E. C. (1981). Economic convergence and divergence in the European community: A survey of the evidence. In: M. Hodges, \& W. Wallace (Eds.), Economic divergence in the European Community, pp. 16-31, London: George Allen and Unwin.

Joseph A., Chiara Osbat, (2016), How you export matters: the disassortative structure of international trade, European Central Bank, Working Paper Series, No 1958 / September 2016 , 
https://www.ecb.europa.eu/pub/pdf/scpwps/ecbwp1958.en.pdf?b8d3afa9e2776a042e7b b3190d9b6f82

Kaitila, Ville, (2013), Specialisation and/or Convergence: Structure of European Exports and Production, ETLA Working Papers No 12, http://pub.etla.fi/ETLA-Working-Papers12.pdf

Kutan, A., \& Yigit, T. (2009). European integration, productivity growth and real convergence: Evidence from the new Member States, Economic Systems, 33(2).

Leonardi, R. (1995). Convergence, cohesion, and integration in the European Union, New York: St. Martin's Press.

Lyncker, K., \& Thoennessen, R. (2015). Regional club convergence in the EU: Evidence from a panel data analysis, Empirical Economics, 2017 (52), pp. 525-553.

Mankiw, N., Romer, D., \& Weil, D. (1992). A contribution to the empirics of economic growth, Quarterly Journal of Economics, 107, pp. 407-438.

Marques, A., \& Soukiazis, E. (1998). Per capita income convergence across countries and across regions in the European Union: Some new evidence, Paper presented at the International Meeting of European Economy, http://citeseerx.ist.psu.edu/viewdoc/download?doi=10.1.1.504.9426\&rep=rep1\&type=p df

Nikolic G., (2011), Convergence of the Export Structure of Romania, Croatia, Serbia and Bosnia-Herzegovina to the Structure of Import Demand in Developed Countries, PANOECONOMICUS, 2011, 3, pp. 393-406, https://core.ac.uk/download/pdf/26224245.pdf

Pirimova V., (2019a) Konvergentsia v strukturata na vanshnata targovia - teoretichni podhodi i predizvikatelstva za Bulgaria, Nauchni trudove na UNSS, 2019, br. 5, s. 83-97 http://unwe-researchpapers.org/uploads/ResearchPapers/RP_vol5_2019_No06_V\%20Pirimova.pdf

Pirimova, V. (2019b) Efektivnost na iznosa i konkurentosposobnost na balgarskata ikonomika, Ikonomicheski i sotsialni alternativi, IK na UNSS, br. 2, s. 56-71

Próchniak, M., \& Witkowski, B. (2013). Time stability of the beta convergence among EU countries: Bayesian model averaging perspective, Economic Modelling, 2013(30), pp. 322-333.

Quah, D. (1996). Empirics for economic growth and convergence, European Economic Review, 40, pp. 1353-1376.

Quah, D. T. (1995). Convergence empirics across economies with (some) capital mobility, Centre for Economic Performance discussion paper no. 25.

Rodrik, D. (2003). Growth strategies, CEPR discussion papers 4100, C.E.P.R. discussion papers.

Rodrik, D. (2011). The future of economic convergence, NBER working paper, 17400

Sala-i-Martin, X. X. (1996). The classical approach to convergence analysis, The Economic Journal, 106(437), pp. 1019-1036, July, 1996.

Scharpf, F. (2016) Forced Structural Convergence in the Eurozone - Or a Differentiated European Monetary Community, MPIfG Discussion Paper 16/15, Max Planck Institute for the Study of Societies, Cologne, December, http://www.mpifg.de/pu/mpifg_dp/dp1615.pdf

Simionescu, M. (2014). Testing sigma convergence across EU-28, Economics \& Sociology, 7, pp. 48-60, No 1, 2014.

Slaughter, M. J. (1997). Per capita income convergence and the role of international trade, American Economic Review, 87, pp. 194-199.

Slaughter, M. J. (2001). Trade liberalization and per capita income convergence: A differencein-differences analysis, Journal of International Economics, 55, pp. 203-228. 
Solow, R. M. (1956). A contribution to the theory of economic growth, Quarterly Journal of Economics, 70, pp. 65-94.

Swan, T. W. (1956). Economic growth and capital accumulation, Economic Record, 32, pp. 334-361.

Van de Coeving, C., (2003), Structural Convergence and Monetary Integration in Europe, MEB Series, №20.

Varbanov T., (2020), Otsenka na konvergentsiyata v Evropeyskia sayuz po razhodi za sotsialna zashtita, Almanah "Nauchni izsledvania", Svishtov, 28/2020 g., s. 157-182 https://www2.uni-svishtov.bg/almanahni/title.asp?title $=1500$

Villaverde, J., \& Maza, A. (2008). Productivity convergence in the European regions, 19802003: A sectoral and spatial approach, Applied Economics, 40(10), pp. 1299-1313.

Von Hagen J., Traistaru, J. (2005) Macroeconomic Adjustment in the New EU Member States, ZEI Working Paper, B https://www.econstor.eu/bitstream/10419/39573/1/495644544.pdf 